ROCZNIKI HUMANISTYCZNE

Tom LXVIII, zeszyt $12-2020$

DOI: https://doi.org/10.18290/rh206812-2

REV. RASTISLAV ADAMKO

\title{
A PREVIOUSLY UNKNOWN REPERTOIRE OF ALLELUIA CHANTS FROM THE 1518 GRADUALE CASSOVIENSE (CLMAE 172A, 172B) ${ }^{1}$
}

In the West, the repertoire of medieval liturgical chants was created relatively early. The main core of Holy Mass repertoire was generated between the $5^{\text {th }}$ and the $8^{\text {th }}$ century. Apart from classical Gregorian repertoire, there is also the post-Gregorian production that-ithin Holy Mass liturgy-is represented by alleluia chants, tropes, sequences and rhymed officia in prayer liturgy. In the West, the latter were drawn up between the $9^{\text {th }}$ and the $15^{\text {th }}$ century, whereas in our countries this type of production came a little later. The result is plenty of interesting chants characterised by tuny melodic with motive elements referring to popular music.

Before the Council of Trent, liturgy was featured by a certain degree of freedom; and this was also manifested-otably - in the various liturgical traditions of single regions, dioceses or centres. The alleluia chants and verses (notably their arrangement and order) offered great opportunities of heterogeneous composition within the repertoire of liturgical monody which appeared at first sight quite monolithic. We are talking about the large group of late Gregorian chants. The German scholar Karl-Heinz Schlager published them in a bilingual publication named Alleluia-Melodien within the edition Monumenta Monodica Medii Aevi (vol. 7-1968, hereinafter SchlagKat and vol. 8 - 1987, hereinafter MonMon VIII). The first volume includes melodies

Prof. ThDr. Rastislav ADAmKo, PhD. - Katolícka univerzita v Ružomberku, Pedagogická fakulta, Katedra hudby; korešpondenčná adresa: Nám. A. Hlinku 56, 03401 Ružomberok; e-mail: rastislav.adamko@ku.sk.

Rev. prof. ThD. Rastislav AdAmKo, Ph.D. - Catholic University in Ružomberok, Faculty of Education Music Department; address for corespondence: Nám. A. Hlinku 56, 03401 Ružomberok, Slovakia; e-mail address: rastislav.adamko@ku.sk.

${ }^{1}$ This study was originated within the frame of management of the project VEGA 1/0105/17-Missale Romanum sign. Rkp. vol. 387 from the Central Library of the Slovak Academy of Sciences - research and source edition. 
created before the year 1100 (notably from western sources); the second volumes includes chants composed after the year 1100 (includes melodies from Central and Eastern Europe). By the way, this giant publication (with almost 1000 melodies) does not include all the existing melodies. For example, let's think of the alleluia chant melodies (32) found in a late medieval bilingual manuscript from early $16^{\text {th }}$ century (probably from the year 1518) - the socalled Graduale Cassoviense sign. Clmae 172a, 172b (abbreviation: Ca I and Ca II). These manuscripts are located in the National Széchényi Library in Budapest (Ca II since 1823 and Ca I since 1941). The above-mentioned source represents not only homophonic liturgical chant, but also the beginnings of polyphony in our territory. The manuscript was used for liturgy in the church of St. Elizabeth in Košice ${ }^{2}$.

The earliest historical mentions of Košice, along the old road from the Balkans to the Baltic lands, called Via magna, date back to the $13^{\text {th }}$ century. The old town of villa Cassa began to take shape after the Tatar invasion, with the early settlements of Saxon colonists in this depopulated territory (between 1242 and 1249). The historians developed four theories concerning the relationship between the original inhabitants and the colonists. By the way, already in the nineties of the $13^{\text {th }}$ century it is no longer mentioned as villa (village) but as civitas (city). The original church was transformed in a new church in Romanesque style. Also, the patron saint changed (from St. Michael to St. Elizabeth of Hungary). It also happened under the influence of German colonists, because St. Elizabeth of Hungary was venerated mainly in Germany where she lived and died in the odour of sanctity (Zubko, Kult Svätej Krvi v Košiciach 19-20).

Starting from the beginning of the $11^{\text {th }}$ century, the territory of the current Archdiocese of Košice was gradually integrated in the ecclesiastical province of Eger. Many liturgical customs and traditions were practically preserved until the interwar period in the $20^{\text {th }}$ century (e.g. common ritual for both dioceses) (Zubko, Kult Svätej Krvi v Košiciach 83).

Thanks to royal privileges, Košice was the second most important city in medieval Kingdom of Hungary (Zubko, Kult Svätej Krvi v Košiciach 27). First, it benefited from the privileges of 1249 (together with the city of Trnava and the Saxons from the Spiš region). Then, in 1319, Charles Robert of Anjou granted Košice merchants' further privileges (i.e. toll exemption in the Abov and Zemplín seats). Quite a generous king for Košice was also Louis I the Great (1342-1382), who granted the same privileges as the capital city of

\footnotetext{
${ }^{2}$ For a fine art analysis of the manuscript (Güntherová and Mišianik 62-64).
} 
Buda, in 1347. Under his government, Košice became the city of negotiations between the Kingdom of Hungary and Poland (Zubko, Kult Svätej Krvi $v$ Košiciach 35). During the greatest flourishing of the city, its municipal authorities decided to build a representative church for the city. Construction works of the Cathedral of St. Elizabeth in Košice began in 1390, but they did not advance so fast. A new impulse to resume intensive work was given by the fire of the original parish church, just before the year 1400 (Zubko, Kult Svätej Krvi v Košiciach 41-42). The new church construction planning was quite generous, based on well-established western patterns. The bourgeoisie of Košice could afford it. Indeed, back then, Košice was an important pilgrimage place and welcomed pilgrims from the whole Central Europe thanks to the relics of the Holy Blood - that were preserved in this city after a Eucharistic miracle happened. A priest accidentally poured consecrated wine (Christ's Blood) on a corporal. Consequently, an image was formed reminding Christ's face. This fact is mentioned in a papal bull from 1402 by means of which Pope Boniface IX granted Košice indulgences and promoted this city to a relevant European pilgrimage site ${ }^{3}$. The miracle took place in the early church of St. Elizabeth, probably after its Romanesque style transformation, under the government of Louis I the Great. Probably just because of this event, the sovereign decided to bestow several privileges to this city and to promote it to second most important city after Buda (32). In order to preserve the relics of the Holy Blood in Košice, they first built the independent chapel of St. Michael, and later transferred the relics to the newly constructed Cathedral of St. Elizabeth. More specifically, the relics were placed in the southern tower, in a special room with a case in a niche, accessible through a double staircase (upwards and downwards). In the sources, the relics are mentioned even in the years 1493 and 1507. This fact proves that the cult of the relics was quite vivid during the whole $15^{\text {th }}$ century and also in the early $16^{\text {th }}$ century (71). It is proved also by five images of Christ's face (mandylion and veraikon) - back then located in the cathedral itself-and by several architectural elements (notably the southern matroneum destined to preserve the relics) (61-71). The last mention of the relics appears in documents from 1604. Radicalisation under Reformation as well as many other religious skirmishes caused the extinction of this cult in Košice (107).

The cathedral of St. Elizabeth was built in three stages. The second stage was completed in 1440 . The last stage-during which the sanctuary was

\footnotetext{
3 “ (...) the Košice parish church of Blessed Elizabeth in the Eger diocese - where long time ago the glorious Blood of our Lord Jesus Christ miraculously appeared.” (Zubko, Kult Svätej Krvi v Košiciach 25)
} 
built - ended at the beginning of $16^{\text {th }}$ century. Nevertheless, the church was used for liturgical purposes since the year 1457 (70).

Due to its geographical position in the heart of a large region, the church and its treasures were exposed to real threats in several occasions. In 14901491, the cathedral was damaged during the siege of Košice by the Polish prince John Albert. The cathedral was also damaged by fires. In that specific period, a historically enormous fire is recorded on 13 April 1556 that destroyed many medieval altars.

The Graduale Cassoviense was quite probably composed in the early $16^{\text {th }}$ century, i.e. at times of the largest flourishing of Košice, where the construction of the cathedral was completed and when the cathedral welcomed plenty of pilgrims from the whole Central Europe. It is possible that-in those times - it was necessary to draw up missals and graduals. The city and its inhabitants seemed to have enough financial means to fulfil this purpose. Quite a large flow of money was brought to the town by the pilgrims who wished to see the relics of Christ's Blood.

The first person who wrote about the provenance of the Graduale Cassoviense was Vincent Blaho (the Father Guardian of the Franciscan convent) who created an index for the manuscript in 1782 . According to him, the manuscript was composed in the $15^{\text {th }}$ century under the reign of Matthias Corvinus. Nevertheless, in the II volume of the gradual (f 273), Edith Hofmann found the date 1518 in one of the painted initials-which was likely to be inserted there by the illuminator ("A Nemzeti Múzeum" 41). In current musicological, fine-art, and artistic studies, scholars were quite persuaded that the manuscript was drawn up for the city of Košice or even in Košice itself (Berkovits, "A Kassai-graduale" 68-88; Güntherová and Mišianik 62-63). So far there is no primary historical evidence of that. Thus, we only have some hypotheses. According to one of these hypotheses, the monumental bilingual gradual was brought to Košice in the $16^{\text {th }}$ century from the city of Oradea Mare (under Turkish occupation) together with other precious objects in order to protect these treasures (Balogh, "Varadinum, Várad vára" 298-299; Kiss, "A true 'Central European' manuscript" 77-89). On the basis of a palaeographic analysis of notation as well as of an analysis of musical repertoire, somebody conjectured that the bilingual gradual was created in the territory of Bohemia.

The Graduale Cassoviense contains a relatively large group of alleluia chants, which are quite extraordinary from a musical point of view. Only a small number of chants show textual peculiarities (in total only 2 chants). The total amount of examined chants is 32 . They shall be classified into groups according to their modality and melodic similarity. 


\section{MELODIES IN THE AUTHENTIC PROTUS}

All. Dorsa eorum (Ca II/256). De evangelistis. Melodic similarity with SchlagKat n. 77a Justi epulentur is visible only up to jubilus. Nevertheless, the verse melody (notably in its central stage) is different. This connection of melody and text (as a given melodic variant) is not found in the Schlager catalogue.

Table 1. Comparison of chants SchlagKat no. 77a All. Justi epulentur and Ca II/256 All. Dorsa eorum

\begin{tabular}{|c|c|}
\hline $\begin{array}{l}\text { SchlagKat no. } \\
\quad 77 \mathrm{a} \\
\text { Justi epulentur }\end{array}$ & 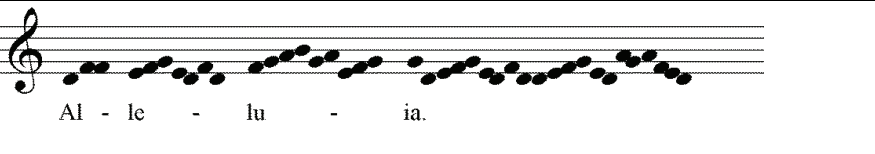 \\
\hline $\begin{array}{c}\mathrm{Ca} \mathrm{II} / 256 \\
\text { Dorsa eorum }\end{array}$ & 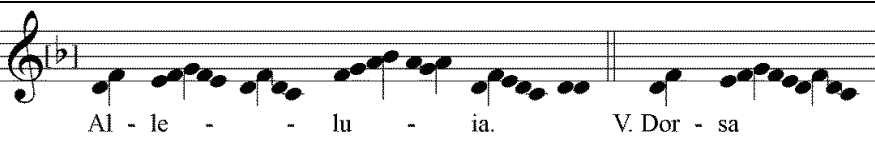 \\
\hline
\end{tabular}

The following three melodies show melodic similarity with the alleluia chant reported in the SchlagKat under no. 74 with the text In omnem terram. Such a combination (between the above-mentioned verse texts and the given melody) is not recorded in currently known databases.

\section{All. Posuisti Domine (Ca II/260). De uno martyre.}

All. Mirabilis Dominus noster (Ca II/263va). De martyribus; it can be defined as one of the variants of the melody of SchlagKat no. 74a.

All. Serve bone et fidelis (Ca II/266v). De uno confessore et pontifice; it is - indeed-a different version of the melody All. Posuisti Domine (Ca II/260), or a free adaptation of the melody of SchlagKat no. 74 .

Table 2. Comparison of chants SchlagKat no. 74 All. In omnem terram with chants Ca II/260 All. Posuisti Domine, Ca II/263va Mirabilis Deus noster and Ca II/266v Serve bone et fidelis

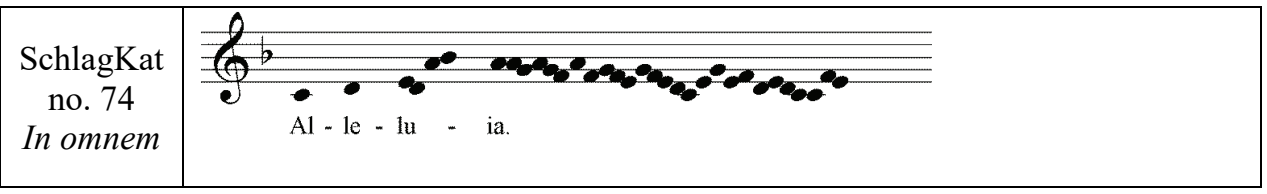




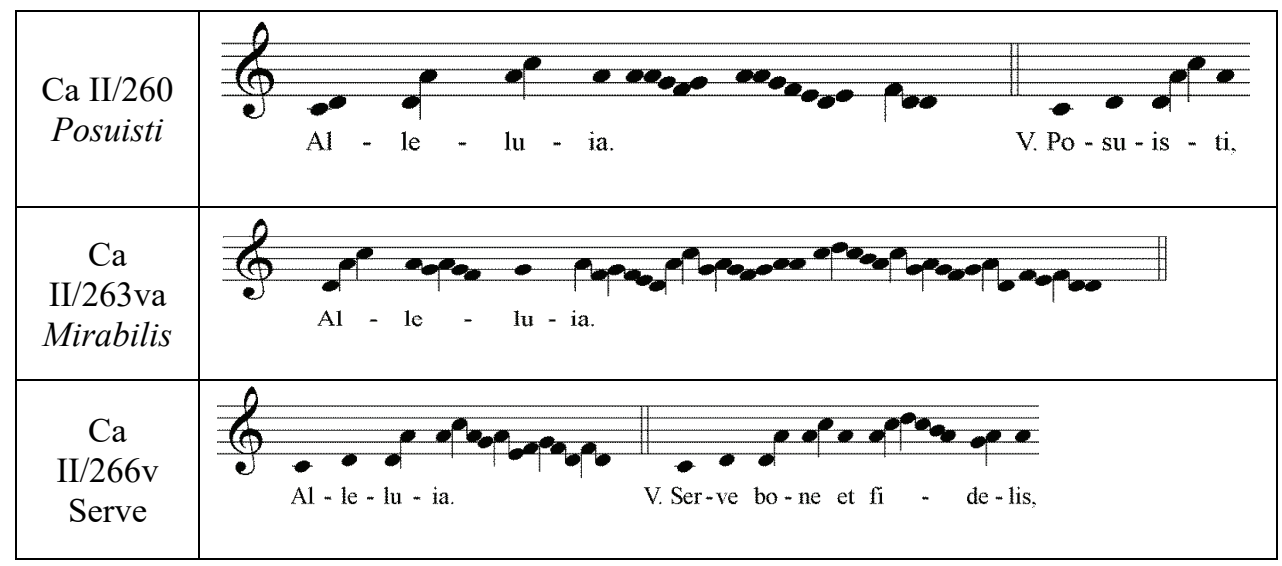

Table 3. Comparison of chants SchlagKat no. 74a and Ca II/260 All. Posuisti Domine

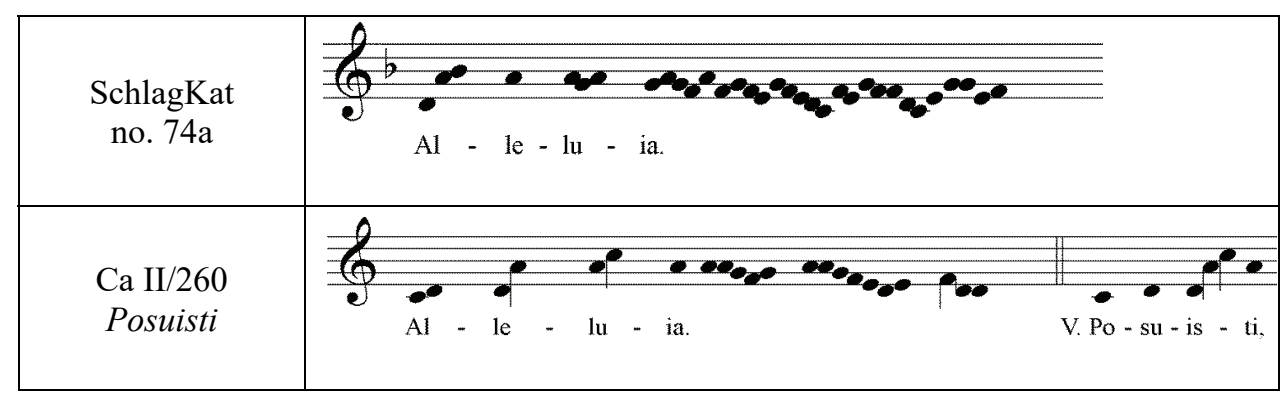

All. Paratum cor meum (Ca II/90v). Dominica XVI. In this chant two different melodies are connected: one for Alleluja and a different one for the verse. The alleluia melody is not found in the Schlager catalogue. We can consider it a melodic variant of SchlagKat no. 52 (In exitu Israel) in $2^{\text {nd }}$ mode. The verse melody is already traditional-SchlagKat no. 203.

Table 4. Comparison of chants SchlagKat no. 52 All. In exitu Israel and Ca II/90v All. Paratum cor meum

\begin{tabular}{|c|c|}
\hline $\begin{array}{c}\text { SchlagKat } \\
\text { no. 52 } \\
\text { In exitu }\end{array}$ & \\
\hline $\begin{array}{l}\text { Ca II/90v } \\
\text { Paratum }\end{array}$ & \begin{tabular}{l} 
Al - le \\
\hline
\end{tabular} \\
\hline
\end{tabular}


In the following three chants we can identify isolated motives that are present also in the SchlagKat chant no. 41 Fulgebunt justi.

All. Fulgebunt justi (Ca II/263vav). De martyribus; a chant that develops the melodic line in a different way than SchlagKat no. 41. The alleluia intro has similar melodic material as SchlagKat no. 140 as well.

All. Haec est vera fraternitas quae numquam (Ca II/198v). Septem dormientium [27. VII.].

All. Haec est vera fraternitas quae numquam (Ca II/262v). De martyribus.

Table 5. Comparison of chants SchlagKat no. 41 All. Fulgebunt justi with melodies Ca II/263vav All. Fulgebunt justi, Ca II/198v All. Haec est vera and $\mathrm{Ca}$ II/262v All. Haec est vera

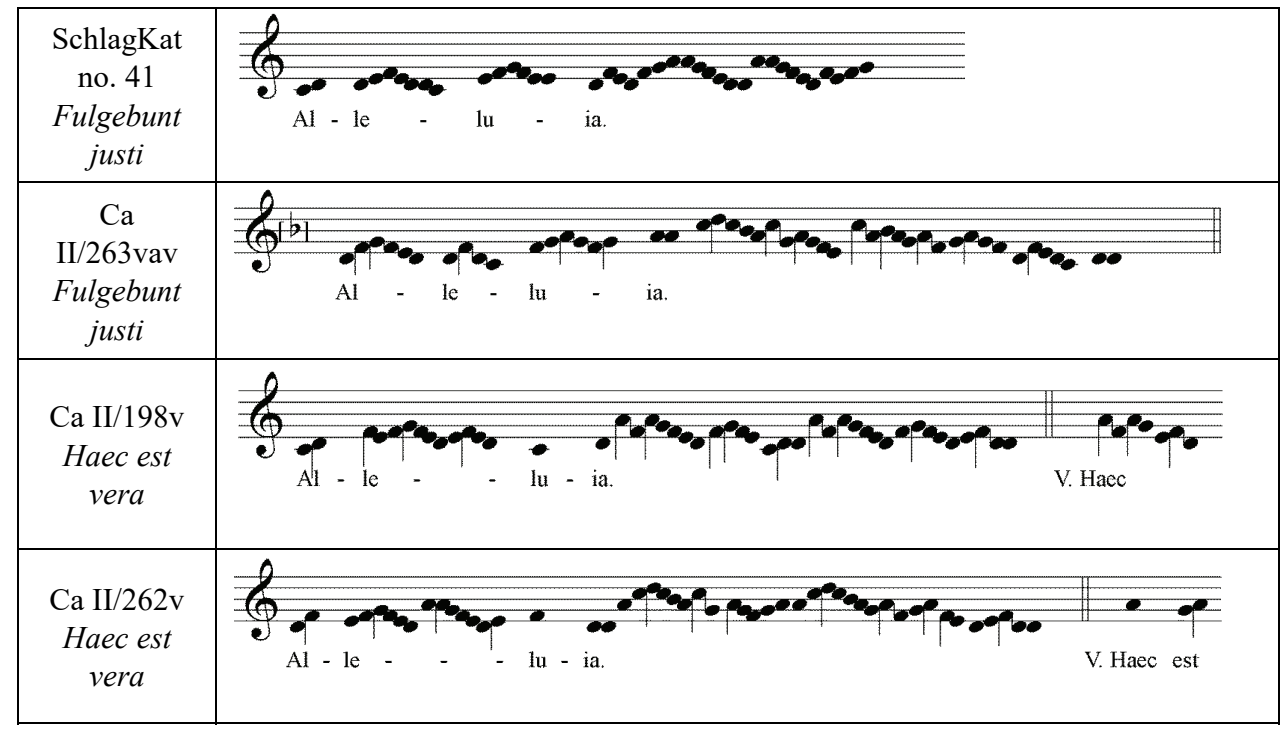

Table 6. Comparison of chants SchlagKat no. 140 All. Christus resurgens and Ca II/263vav All. Fulgebunt justi

\begin{tabular}{|c|c|}
\hline $\begin{array}{l}\text { SchlagKat } \\
\text { no. } 140 \\
\text { Christus } \\
\text { resurgens }\end{array}$ & 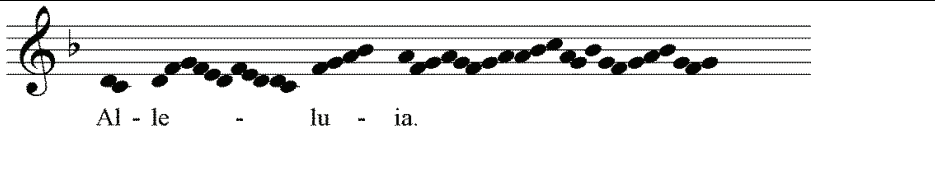 \\
\hline $\begin{array}{l}\text { Ca } \\
\text { II/263vav } \\
\text { Fulgebunt } \\
\text { justi }\end{array}$ & 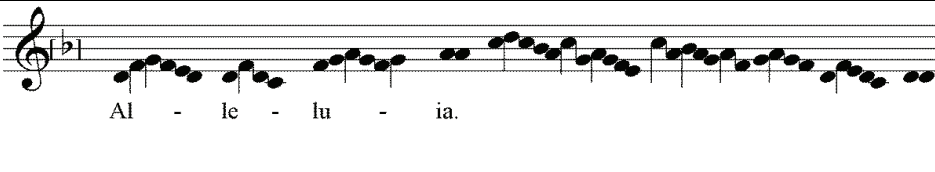 \\
\hline
\end{tabular}


Both chants All. Haec est vera are different in terms of melody ( $1^{\text {st }}$ mode), but also in terms of text and chant, which is generally spread under the incipit Haec est vera fraternitas quae vicit $\left(8^{\text {th }}\right.$ mode, SchlagKat no. 348$)$. The whole second part of the text is new and unknown in the current databases.

Table 7. Comparison of two texts of chant All. Haec est vera fraternitas

\begin{tabular}{|l|l|}
\hline \multicolumn{1}{|c|}{ SchlagKat no. 348 } & \multicolumn{1}{c|}{ Ca II/198v; II/262v } \\
\hline Haec est vera fraternitas, & Haec est vera fraternitas, \\
quae vicit mundi crimina: & quae numquam potuit violari certamine, \\
Christum secuta est, & qui effuso sanguine \\
inclyta tenens regna caelestia. & secuti sunt Dominum. \\
\hline
\end{tabular}

\section{ALLELUIA CHANTS IN THE PROTUS PLAGALIS MODE}

Five alleluia chants appear as different variations for the SchlagKat chant no. 5 and with the younger chant published in MonMon VIII, pp. 243, 673674 Inventa una pretiosa. These are chants in which we can find a few melodic motives from the above-mentioned chant, interconnected with heterogeneous melodic material.

All. Domine in virtute (Ca II/260v). De uno martyre. The same text is also connected with the different melody of SchlagKat no. 222.

All. Beatus vir qui timet (Ca II/256v). De evangelistis. It is quite an old text traditionally relating to an own melody in $5^{\text {th }}$ mode (SchlagKat no. 227). Nevertheless - in Ca-it is recorded with the melody in $2^{\text {nd }}$ mode.

All. Justi autem in perpetuum (Ca II/263). De martyribus. In the central sources from the Kingdom of Hungary, this text is connected with traditional melody of German origin (SchlagKat no. 212). Apart from this one, there are still two different melodies for this text (SchlagKat no. 65 and no. 148). Here, we have the melody in $2^{\text {nd }}$ mode, with similar melodic material as the already mentioned melody All. Inventa una preciosa (MonMon VIII).

All. Inveni David (Ca II/267). De uno confessore et pontifice. In $\mathrm{Ca}$, this Europe-wide popular chant with original melody Dies sanctificatus (SchlagKat no. 27) was replaced by a different melody exploiting similar melodic material as in All. Inventa una preciosa (MonMon VIII).

All. Inventa una preciosa (Ca II/271) - in terms of text and melodyrepresents a variation of the chant placed by K. Schlager in MonMon VIII, pp. 243, 673-674. Here, in the text component, we observe a modification after the word 
Margarita, where we can find the text abiit et vendidit omnia quae habuit et emit eam instead of dedit omnia sua negociator et comparavit eam. From a melodic point of view, the aleluja acclamation starts from the peculiar motive for $2^{\text {nd }}$ mode $(D D C A C D)$ and the main melisma in the syllable le comes out only up to tone $F$, whereas the jubilus is completely missing. In the verse, there are no such long melismas as in the published version. The sources described by Schlager come from Southern Germany and Bohemia.

Table 8. Comparison of chants SchlagKat no. 5 All. Quo progrederis sine filio, MonMon VIII, p. 243 Inventa una pretiosa with several chants from Ca

\begin{tabular}{|l|l|}
\hline $\begin{array}{c}\text { SchlagKat } \\
\text { no. } 5 \\
\text { progrederis }\end{array}$ \\
\hline $\begin{array}{c}\text { MonMon VIII } \\
\text { p. } 243\end{array}$
\end{tabular}




\section{MELODIES IN AUTHENTIC DEUTERUS MODE}

This group is formed by one chant only. It probably found its melodic inspiration out of the range of alleluia chants.

All. Ursula sponsa egregia $(\mathrm{Ca} \mathrm{II} / 235)$. Undecim milium virginum [21. X.]. This chant is not present in the Schlager catalogue or in other comparative manuscripts. It is a late medieval chant with the final $a$ and with typical fourth intervals immediately at the beginning of alleluia, as well as in the course of the verse melody. A very similar melody is present in the responsorium prolixum Alleluia. Omnia quae sunt in caelo (cao006077) ${ }^{4}$, that was sung in the officium destined to the feast of Inventio Sanctae Crucis in the Matins, in the third nocturne.

Table 9. Comparison of chant Resp. Omnia quae sunt in caelo with chant Ca II/235 Ursula sponsa egregia

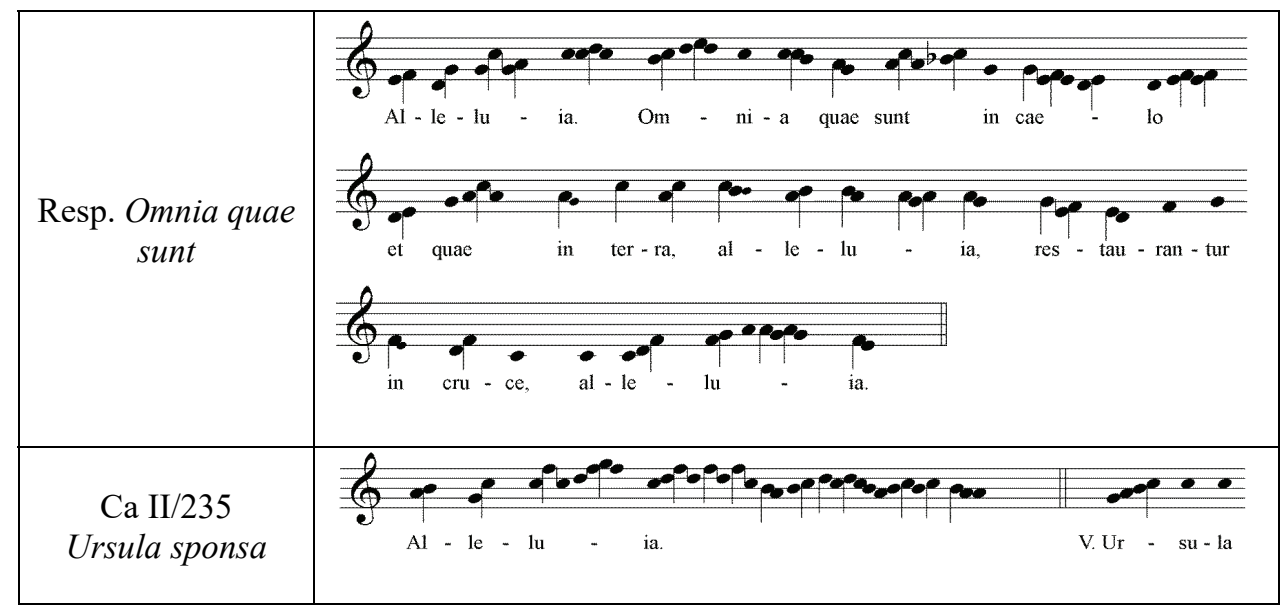

MELODIES IN DEUTERUS MODE WITH SONGLIKE MELODIC

Charles M. Atkinson and G. Kiss define these melodies as: "songlike E-melodic" (liedhafte E-Melodik) (Atkinson, "Agnus Dei" 272; Kiss, "The "liedhafte E-Melodik"” 315-324). These chants are featured by a typical

${ }^{4}$ The CANTUS Database recognises it from a French source Antiphonary from the monastery of St. Maur-des-Fosses from early $12^{\text {th }}$ century. Paris, Bibliothèque nationale de France, Département des Manuscrits, sygn. lat. 12044, f 114r. Cit. according to CANTUS Database. 
songlike melodic with third steps, large intervals, and repeated fixed melodic formulae (e.g. at the beginning of motive efed) forming the whole group of late medieval chants (Example 1). Within this large group, G. Kiss defines two further subgroups. The first subgroup includes chants that are featured by evident common elements. The second subgroup includes chants with less apparent similarities. Nevertheless, G. Kiss acknowledges that the border between these subgroups is not always clear and easy to recognise. This type of melodic was originated in the 13th century in South-German and Bohemian environments. Hence, it was spread to the whole Central Europe (Monumenta Monodica Medii Aevi-Subsidia 6: 90). This melodic was quite appreciated in the Late Middle Ages, as it is witnessed in the source from Košice in which the given melody is utilised in different forms (Example 1).
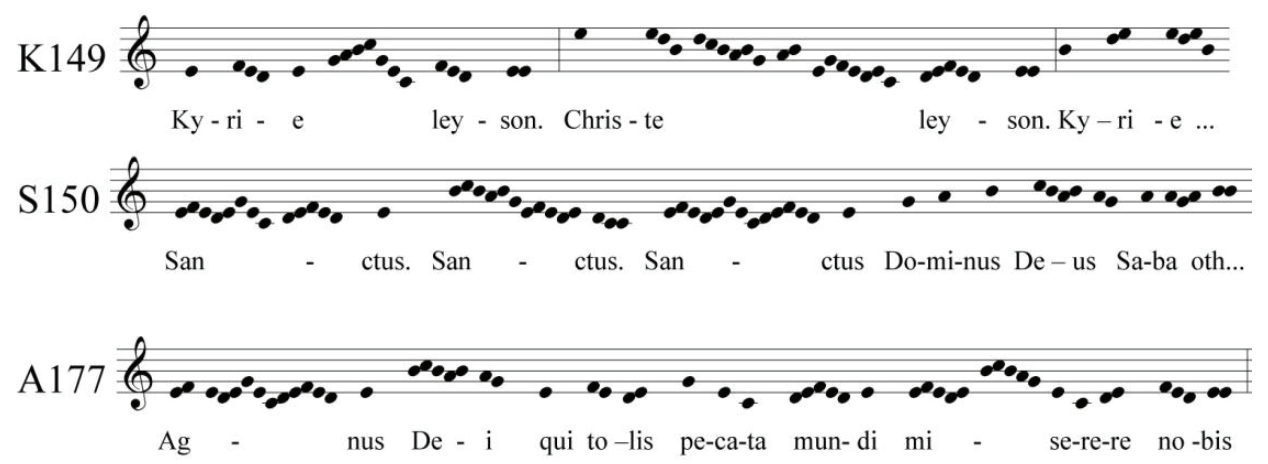

Example 1. Songlike E-melodic in Kyrie 149, Sanctus 150, and Agnus 177 from Ca

The songlike E-melodic became a source of inspiration also for some original alleluia chants in $\mathrm{Ca}$ that - so far-have not been found in other sources.

All. Jam non estis (Ca II/259). De apostolis. This is not the melody classified by Schlager under number 197 in his catalogue.

All. Justus germinabit (Ca II/261). De uno martyre. Compared to traditional versions, the chant has a shortened text. Two final words are missing here: ante Dominum similarly to $\mathrm{GrCl}$, where-by the way-we have a different melody. The notator got it probably wrong when he wrote the $\mathrm{C}$ key in the alleluia melody. That should be on the fourth line, not on the fifth line.

All. Gloria et honore (Ca II/261). De uno martyre. It is also a unique chant that is not recorded in the SchlagKat.

All. Sancti tui Domine florebunt (Ca II/265v). De uno confessore. Traditionally, this text is connected with the proper melody of SchlagKat no. 272. 
In $\mathrm{Ca}$ we have a different melody, without jubilus. At the end of the verse text the following words are missing: ante te. Quite a significant similarity with this melody is shown by All. O Maria mater Christi from Graduale Strigoniense of Tamás Bakócz (GrStr) f II/83v (Monumenta Monodica Medii Aevi 8: 345, 724-725).

All. Pretiosa in conspectu (Ca II/265v). De uno confessore. According to K. Schlager this text has two melodies: the first one of French originSchlagKat no. 282 in $8^{\text {th }}$ mode, which is quite rare in the sources from the Kingdom of Hungary; and the second one is characterised by unknown provenance-SchlagKat no. 200. None of them matches the melody reported in Ca. It is a relatively complex melody, without jubilus. A similar melody is included in GrStr f II/82v (All. Ave stillans melle; Monumenta Monodica Medii Aevi 8: 79, 600).

All. Disposui testamentum (Ca II/267). De uno confessore et pontifice. The chant text is recorded already in the oldest Holy Mass sources and it is traditionally related to the melody Dies sanctificatus (SchlagKat no. 27). Nevertheless, it has a different melody in $\mathrm{Ca}$.

All. Elegit te Dominus (Ca II/267v). De uno confessore et pontifice. In the sources from the Kingdom of Hungary, this chant is quite rare and it has a different melody (Redemptionem misit SchlagKat no. 28), as in this manuscript.

All. Veni electa mea (Ca II/270v). De virginibus. The text of the alleluia verse presents several melodies. In GrStr we observe an adulteration of SchlagKat 10 melody. Nevertheless, in Ca there is a completely new melody, unknown to Schlager. Hallelujah is without jubilus and in the verse we observe two longer syllabic segments (with fourth and fifth intervals).

All. Aemulor enim vos $(\mathrm{Ca} \mathrm{II} / 271 \mathrm{v})$. De virginibus. This text was already known in the $11^{\text {th }}$ century. K. Schlager found it with melody in $1^{\text {st }}$ mode (SchlagKat no. 45). Generally speaking, it is quite a rare chant.

Table 10. Chant comparison with songlike melodic in $\mathrm{Ca}$

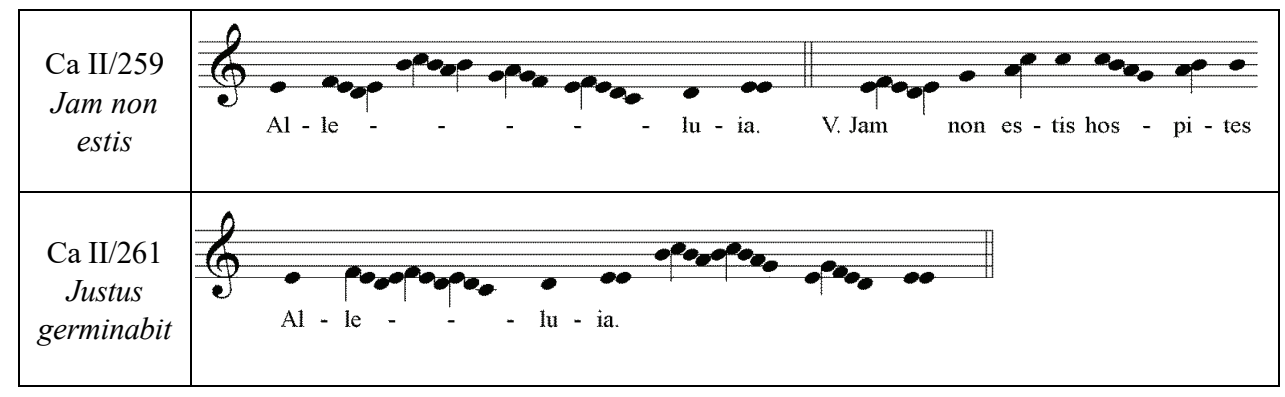




\begin{tabular}{|c|c|}
\hline $\begin{array}{l}\text { Ca II } / 261 \\
\text { Gloria et } \\
\text { honore }\end{array}$ & 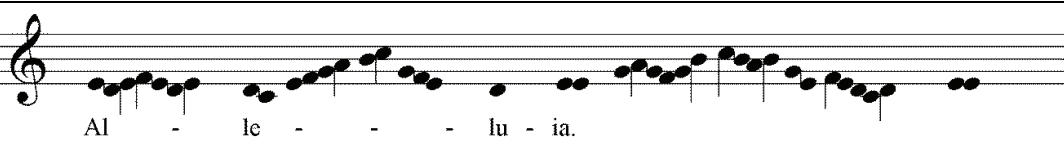 \\
\hline $\begin{array}{c}\text { Ca II } / 265 \mathrm{v} \\
\text { Sancti tui }\end{array}$ & 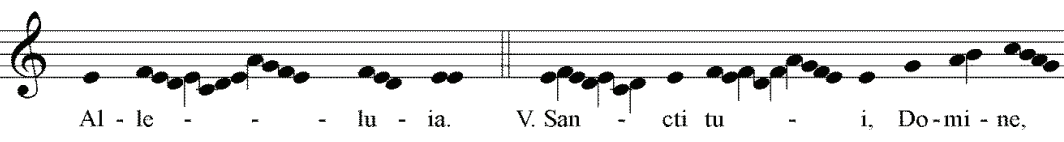 \\
\hline $\begin{array}{c}\text { Ca II } / 265 \mathrm{v} \\
\text { Pretiosa }\end{array}$ & 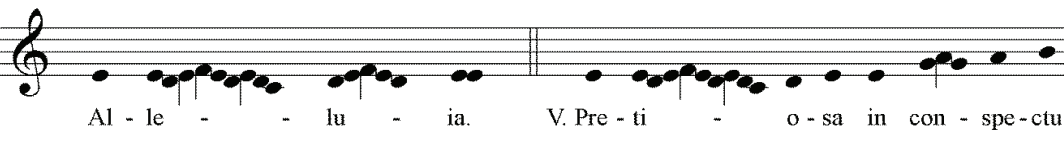 \\
\hline $\begin{array}{l}\text { Ca II/267 } \\
\text { Disposui }\end{array}$ & 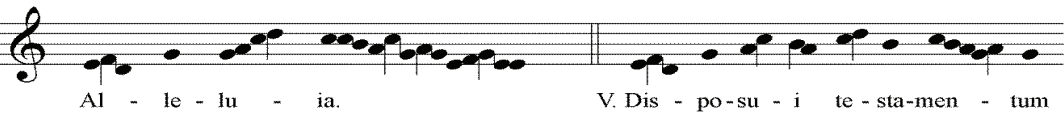 \\
\hline $\begin{array}{c}\mathrm{Ca} I \mathrm{II} / 267 \mathrm{v} \\
\text { Elegit te }\end{array}$ & 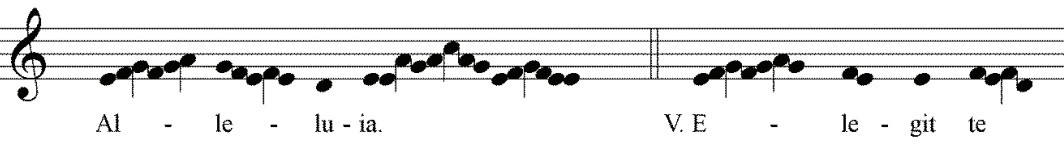 \\
\hline $\begin{array}{l}\text { Ca II } / 270 v \\
\text { Veni electa }\end{array}$ & 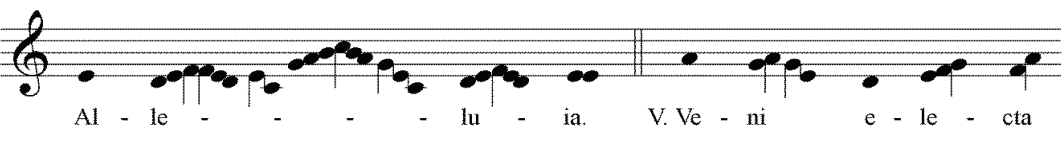 \\
\hline $\begin{array}{l}\text { Ca II/271v } \\
\text { Aemulor }\end{array}$ & 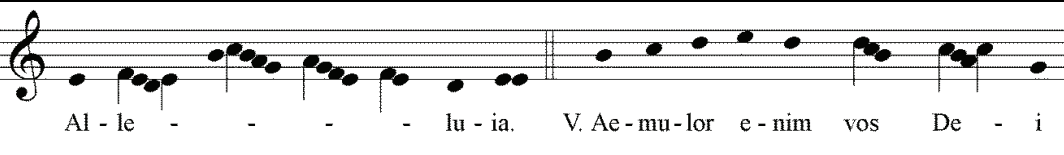 \\
\hline
\end{tabular}

\section{ALLELUIA CHANT IN AUTHENTIC TRITUS}

All. Beatus vir qui suffert (Ca II/268). De uno confessore et pontifice. J. Pikulik acknowledges two melodies for this text: (i) SchlagKat no. 62 and (ii) a second melody - most probably SchlagKat no. $77 \mathrm{a}^{5}$, both of them in $1^{\text {st }}$

${ }^{5}$ We have found the given melody with the text Beatus vir qui suffert in a gradual from Jasna Góra (Graduale Conventus Vielunensis Ordinis s. Pauli Primi Eremitae) from the $16^{\text {th }}$ century. Częstochowa, Jasna Góra, Archiwum Rękopisów muzycznych Ojców Paulinów, sign. R-659, III913ms. 2400, f 154v/173. 
mode. By the way, in $\mathrm{Ca}$ there is a further melody (the third one), in $5^{\text {th }}$ mode, whose incipit is similar to SchlagKat no. 227 Beatus vir qui timet. The alleluia is relatively short, without jubilus. The verse is dominated by syllabic flow of melody, with typical progression by thirds $(\mathrm{Fac})$.

Table 11. Comparison of chant SchlagKat no. 227 All. Beatus vir qui timet with chants Ca II/268 All. Beatus vir qui suffert

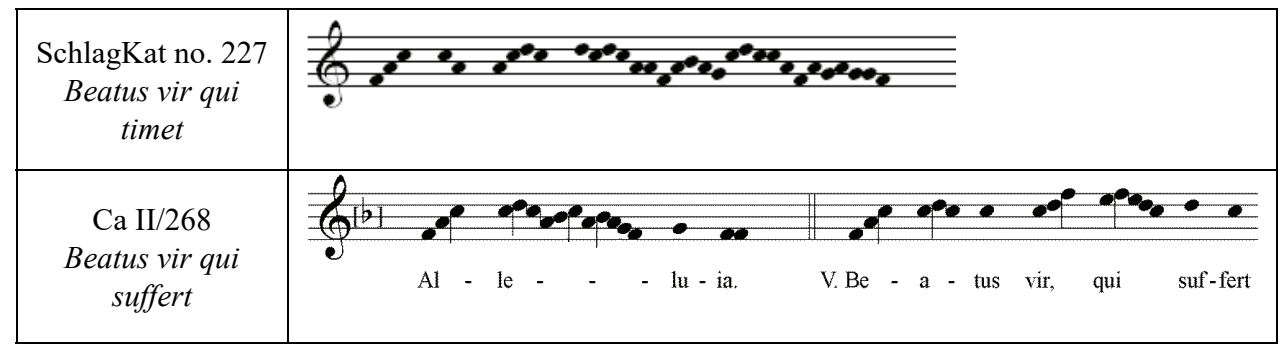

\section{ALLELUIA CHANTS IN PLAGAL TRITUS}

The following chants have common motives with the chant All. Ave benedicta Maria/Tp O Maria caeli via (Ca II/247)-MonMon VIII, pp. 46-48, 587-591.

All. Vox sancti Bartholomaei (Ca II/217). In die sancto [24. VIII.]. The melody from the presented source with final $F$ is not included in the Schlager's catalogue. The text of this chant is present in two sources from the Kingdom of Hungary: GrTra and $\mathrm{GrFu}$; and in one Bohemian source: GrHor. By the way, in each one of them there is a different melody. In GrTra, the text is adapted to the melody In conspectu angelorum (SchlagKat no. 165); in $\mathrm{GrFu}$, the melody of the alleluia acclamation is evidently similar to All. Omnes gentes plaudite (SchlagKat no. 144); and in GrHor, we have an unknown melody with final $G$. J. Pikulik found the text of this chant also in two Polish diocesan graduals (Pikulik 319).

All. Dorsa eorum (Ca II/229). In die sancti Mathei [21. IX.]. This chant was known in Southern Germany, Austria, Bohemia, and Kingdom of Hungary $^{6}$. With regard to $\mathrm{Ca}$, we observe a different melodic version with final $F$. We didn't find it in the Schlager's catalogue or in other accessible sources from the Kingdom of Hungary. The melodic material reveals resemblance also

\footnotetext{
${ }^{6}$ Compare: MonMon XVIII, pp. 149-150, 626-628.
} 
with the sequence Gaude Sion quod egressus (AH 53:120, p. 140) on the feast of St. Elizabeth of Hungary.

All. Os justi meditabitur (Ca II/268). De uno confessore et pontifice. The ancient text with late medieval melody, with final $F$ and its ambitus are duodecimal (C-f). The melodic course is featured by a dominant syllabic flow; and in the melody of alleluia there is no jubilus. Traditionally, this text is connected with the proper melody of $1^{\text {st }}$ mode (SchlagKat no. 63). The chant is rare in Central European sources, regardless of melody.

Table 12. Comparison of chant MonMon VIII, pp. 46-48 All. Ave benedicta with chants from Ca II

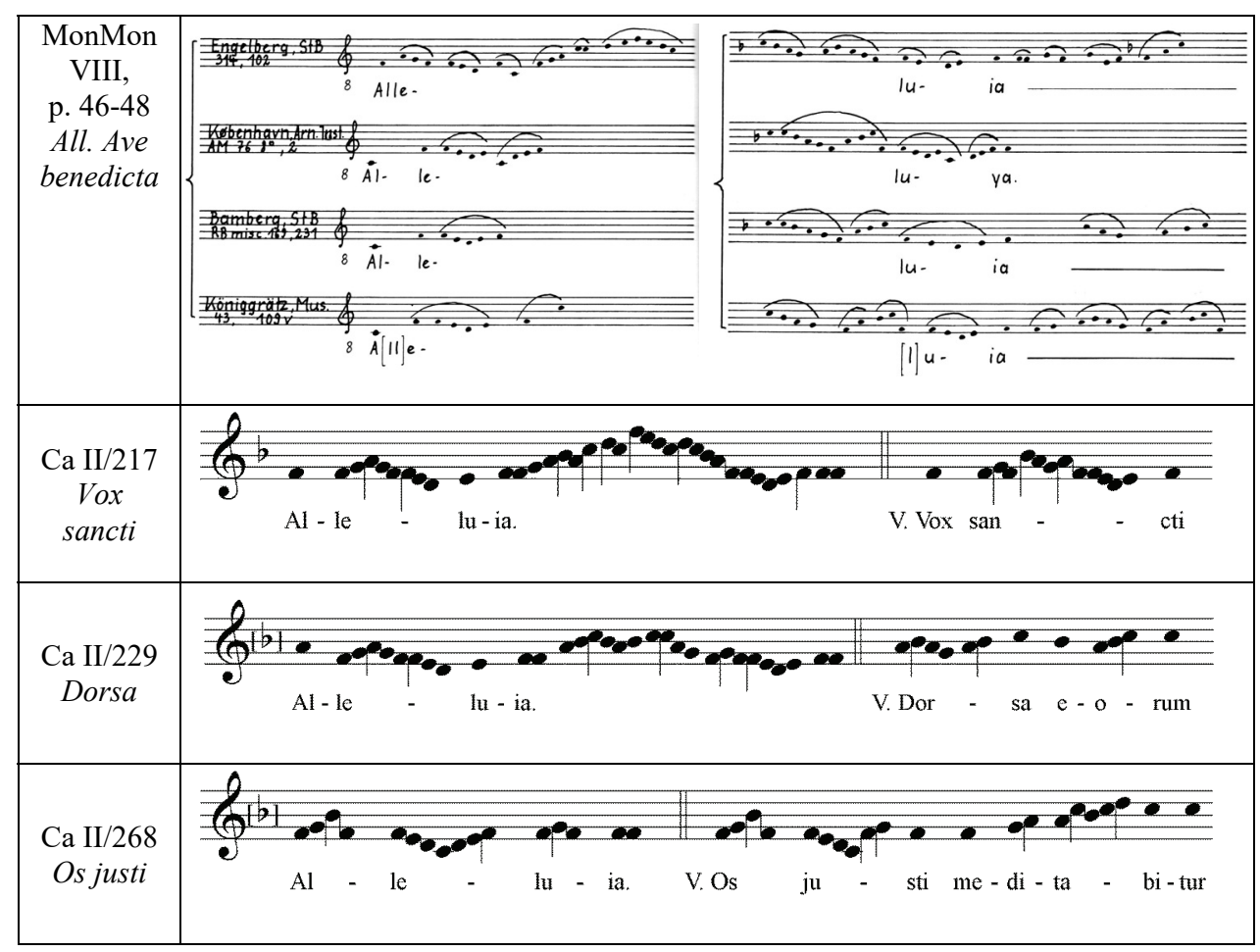

The other two chants have common introductory motive coming out from the chant All. Domine in virtute (SchlagKat č. 222).

All. Sophia mater sancta (Ca I/424). De sancta Zophia [15. V.]. The melody is a development of the chant Domine in virtute-SchlagKat no. 222. Nevertheless, the text is original (so far it was not found in any other sources). 
All. Exsultent justi (Ca II/263va). De martyribus. It is another-so far unknown - melody with traditional text, in $6^{\text {th }}$ mode. The traditional melody (SchlagKat no. 166) has got the final $C$ or $E$.

Table 13. Comparison of chant SchlagKat no. 222 All. Domine in virtute with chants from $\mathrm{Ca}$

\begin{tabular}{|c|c|c|}
\hline $\begin{array}{l}\text { SchlagKat } \\
\text { no. } 222 \\
\text { Domine in } \\
\text { virtute }\end{array}$ & 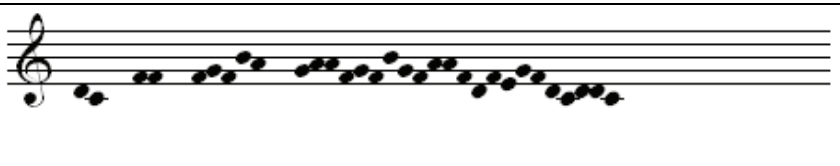 & \\
\hline $\begin{array}{c}\text { Ca I/424 } \\
\text { Sophia }\end{array}$ & 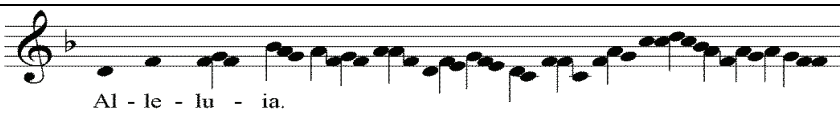 & 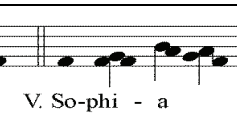 \\
\hline $\begin{array}{c}\mathrm{Ca} \mathrm{II} / 263 \mathrm{va} \\
\text { Exsultent }\end{array}$ & 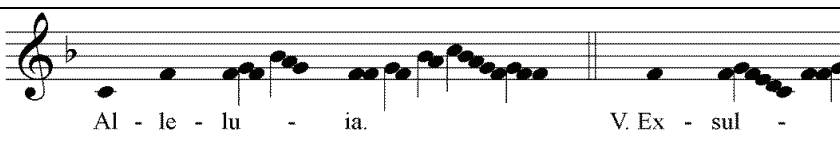 & $P \cdot p^{4} p_{\text {tent }}$ \\
\hline
\end{tabular}

\section{MELODIES IN TETRARDUS}

All the three following melodies of alleluia chants from $\mathrm{Ca}$ have a common introductory motive with upward fourth intervals, as we can also find in the incipit of another chant: Ant. Venite benedicti Patris mei (Feria 2, Hebdomada 1 Quadragesimae).

All. Gaudete justi (Ca II/263v). De martyribus. The work has a traditional text, but is features an untraditional melody in $8^{\text {th }}$ mode which is not included in SchlagKat.

All. Sancti tui Domine benedicent (Ca II/264). De martyribus. It is a chant in $8^{\text {th }}$ mode, whose melody is not found in the Schlager's catalogue. In Central European sources this text presents a melody in $2^{\text {nd }}$ mode (SchlagKat no. 27-Dies sanctificatus).

All. Justum deduxit Dominus (Ca II/268v). De uno confessore et pontifice. The text of this verse appeared in several melodies: SchlagKat no. 321 or Dies sanctificatus (SchlagKat no. 27). In Ca we can observe a melody that is not recorded in the Schlager's catalogue. 
Table 14. Comparison of chant Ant. Venite benedicti Patris mei with chants from $\mathrm{Ca}$

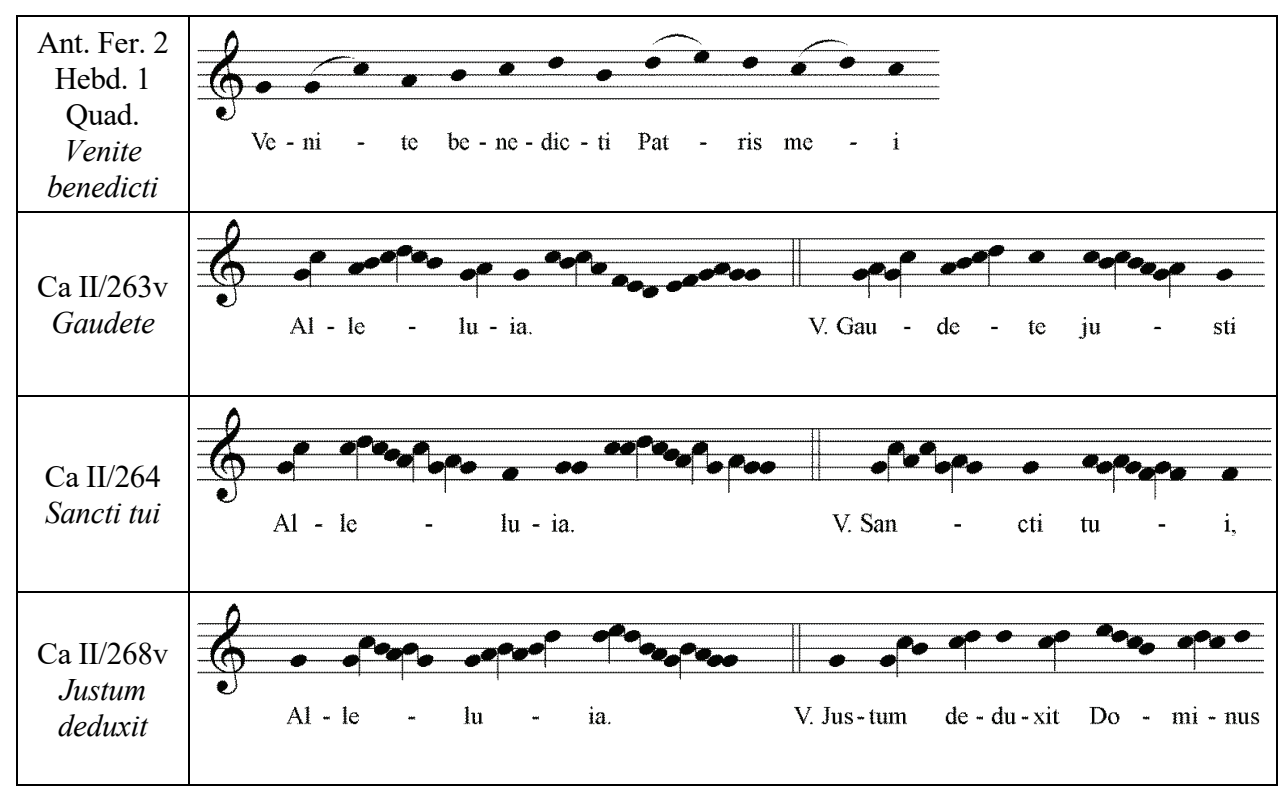

\section{CONCLUSION}

The main common feature of the above described 32 alleluia chants from the Graduale Cassoviense resides in the fact that they are so far recorded only in this source. They are not present in any of the two Schlager's catalogues and not even in the internet databases CANTUS, CANTUS Index or in single national databases. Probably enough, they are the result of local production, both in terms of melody and-at larger scale-in terms of text. All the above-mentioned chants are variations of already existing melodic patterns that are not resulting only from chants of the same formal type, but also from chants destined to fulfil a different function in liturgy. A typical characteristic of this production is the use of established melodic motives. The authors of these melodies actually connected such motives to new entities with the help of the centonization technique.

According to the examined repertoire, we can observe that people were no longer bound by Gregorian aesthetics in Late Middles Ages. The new production was influenced by popular music, preferably by songlike melodic (major and minor scale). It is manifested by the dominance of some specific 
modes $\left(1^{\text {st }}\right.$ mode- 8 chants; $6^{\text {th }}$ mode- 5 chants $)$ and by the frequent choice of the so-called songlike E-melodic ( 9 chants).

In these terms, the Graduale Cassoviense appears as a precious source of late medieval post-Gregorian local musical creativity in the Central European environment.

\section{BIBLIOGRAPHY}

Atkinson, Charles Mercer. “Agnus Dei”. Die Musik in Geschichte und Gegenwart, Sachteil, vol. 1, edited by Ludwig Finscher, Bärenreiter Metzler, 1994, p. 272.

Balogh, Jolán. "Varadinum, Várad vára”. Müvészettörténeti Füzetek 13/2, Akadémiai Kiadó, 1982, pp. 149-150.

Berkovits, Ilona. “A Kassai-graduale és a XVI. századi kassai festészet.” Emlékkönyv Gerevich Tibor születésének 60. évfordulójára, Franklin-Társulat, 1942, pp. 68-72.

Güntherová, Alžbeta, and Ján Mišianik. Stredoveké knižná mal’ba na Slovensku. Slovenské vydavatel'stvo krásnej literatúry, 1961.

Hofmann, Edith. “A Nemzeti Múzeum Széchényi Könyvtárának illuminált kéziratai.” Magyar Könyvszemle, vol. 34, no. 1, 1927, pp. 1-43.

Kiss, Gábor, Zsuzsa Czagány, and Robert Klugseder, editors. Ordinariums-Gesänge in Mitteleuropa Repertoire-Übersicht und Melodienkatalog. Monumenta Monodica Medii Aevi-Subsidia, vol. 6. Bärenreiter, 2009.

Kiss, Gábor. “A true 'Central European' manuscript: the Graduale Cassoviense from 1518.” Musica Mediaeva Liturgica II. Zborník príspevkov z muzikologickej konferencie, edited by Rastislav Adamko, Verbum, 2016, pp. 77-89.

Kiss, Gábor. "The 'liedhafte E-Melodik'.” Studia Musicologica Academiae Scientiarum Hungariae, vol. 40, no. 4, 1999, pp. 315-324, www.jstor.org/stable/902501. Accessed 23 November 2020.

Pikulik, Jerzy. Polskie graduały średniowieczne. Wydawnictwo UKSW, 2001.

Schlager, Karlheinz, editor. Alleluia-Melodien ab 1100, vol. 2. Monumenta Monodica Medii Aevi, vol. 8. Bärenreiter, 1987.

Schlager, Karlheinz, editor. Alleluia-Melodien bis 1100, vol. 1. Monumenta Monodica Medii Aevi, vol. 7. Bärenreiter, 1968.

Zubko, Peter. Dejiny Košickej cirkvi v prameňoch (1803-2006), Edícia Dejiny Košického arcibiskupstva, vol. 5. Vydavatel'stvo Michala Vaška, 2006.

Zubko, Peter. Kult Svätej Krvi v Košiciach: Rozprávanie o stratených stredovekých relikviách. Viliam Ščiavnický, 2012. 


\section{NIEZNANY DOTĄD REPERTUAR ŚPIEWÓW ALLELUJATYCZNYCH GRADUAEU Z KOSZYC Z 1518 ROKU (CLMAE 172A, 172B)}

\section{Streszczenie}

Koszycki Graduał to późnośredniowieczny rękopis muzyczno-liturgiczny, który oprócz standardowego repertuaru gregoriańskiego zawiera także oryginalne śpiewy lokalne. W tym manuskrypcie jest kilka śpiewów allelujatycznych, które nie zostały jeszcze zidentyfikowane w innych źródłach i nie są zarejestrowane w istniejących bazach opublikowanych lub elektronicznych. Porównanie tych śpiewów ze sobą oraz z innym repertuarem daje możliwość wskazania ich kontekstu genetycznego i uwarunkowań. Repertuar ten jest świadectwem eksplozji muzycznej i poetyckiej twórczości lokalnej późnego średniowiecza w Europie Środkowej i Wschodniej. Twórczość ta wykazuje jednak inne niż gregoriańskie założenia estetyczne, dlatego można ją określić jako postgregoriańską.

Słowa kluczowe: katedra w Koszycach; koszycki graduał; repertuar postgregoriański; śpiewy alleluja; modalność.

\section{A PREVIOUSLY UNKNOWN REPERTOIRE OF ALLELUIA CHANTS \\ FROM THE 1518 GRADUALE CASSOVIENSE (CLMAE 172A, 172B)}

\section{Summary}

The Graduale Cassoviense is a late medieval musical-liturgical manuscript. Apart from the standard Gregorian repertoire, it also contains original local chants. Moreover, it also includes several alleluia chants that - so far-have not been found in any other sources or reported in the existing databases. A mutual comparison of these chants (as well as their comparison with other repertoires) provides a chance to show their genetic connections and conditionality. The repertoire shows a late medieval explosion of local musical and poetic production in the territory of Central and Eastern Europe. Nevertheless, this production shows different aesthetical bases and rules than the typical Gregorian ones. For such reasons, we can define it as a post-Gregorian work.

Key words: Cathedral of St. Elizabeth in Košice; Graduale Cassoviense; post-Gregorian repertoire; alleluia chants; modality. 